DOI: http://dx.doi.org/10.33846/hn50202

http://heanoti.com/index.php/hn

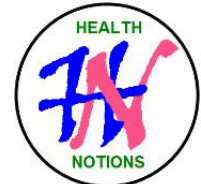

RESEARCH ARTICLE

URL of this article: http://heanoti.com/index.php/hn/article/view/hn50202

\title{
Anticoagulant Activity of Dayak Onion Bulb (Eleutherine bulbosa) Extract on Human
} Blood Samples

\author{
Anik Handayati $^{1(\mathrm{CA})}$, Syamsul Arifin ${ }^{2}$, Monica Putji Astuti ${ }^{3}$ \\ ${ }^{1}$ Department of Medical Laboratory Technology, Poltekkes Kemenkes Surabaya, Indonesia; \\ anik_handayati@yahoo.co.id (Corresponding Author) \\ ${ }^{2}$ Department of Medical Laboratory Technology, Poltekkes Kemenkes Surabaya, Indonesia \\ ${ }^{3}$ Department of Medical Laboratory Technology, Poltekkes Kemenkes Surabaya, Indonesia
}

\begin{abstract}
Cardiovascular disease can occur due to disruption of the hemostatic system by forming blood clots in blood vessels, or commonly known as deep vein thrombosis. The curative action that has been carried out in the form of heparin anticoagulant administration had many side effects such as bleeding, hematuria, thrombocytopenia, and hypersensitivity; therefore, alternative anticoagulant ingredients such as onion bulbs have emerged. Dayak onion bulb (Eleutherine bulbosa) is known to contain eleutherinol compound, which has anticoagulant activity. This study aims to determine the potential anticoagulant activity of Dayak onion bulbs extract (Eleutherine bulbosa) on human blood samples. This anticoagulant activity test was carried out by observing the length of time for blood clotting in the extract treatment group with several concentrations $(0,10,12.5,16,25$, and $50 \%)$ by Clotting Time (Lee-White) method. The results showed a significant delay in blood coagulation time in the group treated with Dayak onion bulbs extract as increasing the concentration. About 50\% Dayak onion onion bulb extract was showed a twofold increase in blood coagulation time thanthat of no extract administration. So that, Dayak bulb onion has the opportunity to be an alternative natural anticoagulant.

Keywords: anticoagulants; Dayak onion bulbs (Eleutherine bulbosa); clotting time
\end{abstract}

\section{INTRODUCTION}

The mechanism of hemostasis is divided into three stages, namely vasoconstriction of blood vessels, cellular reactions to platelet plug formation, and biochemical reactions of fibrin formation. If the blood vessels are injured, there will be vasoconstriction of the blood vessels, in the form of reduced blood flow to the blood vessels. This condition triggers the formation of a platelet plug due to the attachment of platelet clusters in the blood vessels $^{(1)}$. This hemostatic system if it is obstructed or excessive, will contribute to problems in the form of spontaneous bleeding to deep vein thrombosis, respectively. This thrombosis condition can trigger vascular diseases such as myocardial infarction, brain embolism (stroke), ischemia and other vascular diseases ${ }^{(2)}$.

A study from the World Health Organization (WHO) (2010) states that ischemic heart disease and stroke are the most significant contributors to death in the world. Until 2014, it was recorded that more than 17.3 million people worldwide died from heart and blood vessel disease. The death rate from ischemic heart disease increased by $35 \%$, of which 3.5 million people died from thrombosis. Similar conditions also occur in Indonesia, where 15 out of 1000 people or nearly 2.8 million suffer from heart disease. The increase in the incidence of thrombosis reached $3.57 \%$ from 1997 to $19.1 \%$ in 2007 . Thus, the researchers sought various ways to prevent and treat thrombosis.

Healing therapy that is often recommended to treat thrombotic disorders and clots in the coronary arteries is anticoagulant ${ }^{(3,4)}$. Heparin, hydroxycumarin, and their derivatives have a significant role in clinical treatment ${ }^{(5)}$. The widespread use of heparin shows several side effects such as bleeding, hematuria, thrombocytopenia and hypersensitivity, despite its vigorous anticoagulant activity ${ }^{(6)}$. This weakness is one of the reasons for the continuous search for safer alternative anticoagulant therapy.

Research on anticoagulants from natural ingredients such as garlic (Allium sativum) and Dayak onions (Eleutherine bulbosa) has been carried out ${ }^{(7,8)}$. Garlic contains allicin and ajoene compounds which have anticoagulant potential. Meanwhile, Dayak onion is a typical Kalimantan plant that has been used for a long time by Bornean people as a traditional medicine to accelerate breast milk, prevent breast cancer, lowering high blood pressure, antidiabetes, lowering cholesterol and is believed to be able to prevent stroke. These Dayak onion bulbs have been studied for their phytochemical compounds including alkaloids, flavonoids, polyphenols, monoterpenoids and sesquiterpenoids as well as quinones which have antioxidant, antimicrobial, antiseptic and anti-inflammatory properties ${ }^{(8)}$. One of the chemical compounds of Dayak onion bulbs, namely eleutherinol, can prevent hypertension, lower cholesterol levels in the blood, reduce fat blood levels, prevent atherosclerosis, reduce prothrombin, platelet anti-aggregation activity ${ }^{(9,10,11)}$. 
This study aims to test the anticoagulant activity of Dayak onion bulb extract (Eleutherine bulbosa) against human blood samples in-vitro in various extract concentrations so that it will be known the optimal concentration of administration of blood clotting time in human blood samples.

\section{Materials}

\section{METHODS}

Three months old Dayak onion (Eleutherine bulbosa) bulb was obtained from Pampang Cultural Tourism Village, District of North Samarinda, Samarinda City, Province of East Kalimantan. Ethanol $96 \%$ analytical grade (Merck, Darmstadt, Germany) was used in this study.

\section{Extraction of Dayak Onion (Eleutherine bulbosa) bulb}

Simplicia powder of Dayak onions bulb was prepared by washing, cutting roots and leaves, slicing with a thickness of $1-2 \mathrm{~mm}$. The thin cut of the sample was oven-dried at $500 \mathrm{C}$ for 8 hours, subsequently cooled down for a moment. The sample was mashed in a blender, sifted, and store in an air-tight container (BPTP Kalteng). A total of 500 grams of Simplicia powder with $2500 \mathrm{~mL}$ of $96 \%$ ethanol solvent or with a ratio of 1: 5. Dayak onion onion bulb extract was obtained by maceration technique for three days. The extract was evaporated using a rotary vacuum evaporator in a water bath at $60^{\circ} \mathrm{C}$ for 90 minutes. About 35 grams of the thick extract was reconstituted with $96 \%$ ethanol to obtain a concentration of $10 \%, 12.5 \%, 16 \%, 25 \%$ and $50 \%$ Dayak onion onion bulb extract.

\section{Human Blood Sampling}

Nine subjects carried out blood sampling were drawn from the median cubital vein using a $5 \mathrm{~mL}$ disposable syringe (Terumo, Tokyo, Japan). The volume of blood samples taken from each person was $6 \mathrm{~mL}$, with test replications of eight times.

\section{In-vitro analysis of blood clotting time}

Blood clotting time analysis with the addition of Dayak onion bulb extract was carried out according to the Lee-White method with modification ${ }^{(17)}$. Six test tubes, each added $1 \mathrm{~mL}$ of blood and extract of Dayak bulb concentrations of $0 \%, 10 \%$, $12.5 \%, 16 \%, 25 \%$, and $50 \%$. The blood clotting time of 120 minutes is measured using a stopwatch, where every 30 seconds the tube is lifted and tilted to see the presence or absence of blood clots ${ }^{(7)}$. This test was replicated 8 times according to the Federer.

\section{Statistical Analysis}

Data were analyzed for normality and homogeneity using the Kolmogorov-Smirnov test and Levene's test with a significance level of 0.05 . The hypothesis was performed using the one-way ANOVA, followed by the post hoc test if there were significant differences data $(\mathrm{p}<0.05)$. All tests were used in IBM Statistics SPSS 23.

\section{RESULTS}

Anticoagulant activity test of Dayak onion bulb extract (Eleutherine bulbosa) in various concentrations is presented in Table 1. Human blood samples without the addition of Dayak onion bulb extract did not have an inhibitory effect on blood clotting. This result corresponds to the length of time for normal blood clots, which was about 4-8 minutes. By increasing the concentration of the Dayak onion bulb extract, it could also increase the blood clotting time, compared to the control.

Data in Table 1 was shown that the blood clotting time in samples with the administration of 25 and 50\% Dayak onion bulb extract was twice as long as the control. Similar increasing blood clotting time was alsooccurred in the addition of extracts $10,12.5$, and 16 by $38 \%, 52 \%$ and $69 \%$ compared to those without extract administration, respectively. This condition was indicated that Dayak onion bulb extract had the potential anticoagulant activity at all concentrations.

Of the eight replications of the analysis, Table 1 was presented that the data were normally distributed and homogeneous, through the Kolmogorov-Smirnov normality test and the Levene test. From the results of the oneway ANOVA analysis, followed by the post hoc test were showed that all treatment groups had an average value between treatment groups that significantly different.

Table 1. Results of Dayak bulbs extract anticoagulant activity test in various concentrations $(0,10,12.5,16,25$, and 50\%) on human blood samples

\begin{tabular}{|c|c|c|c|c|c|c|}
\hline \multirow{2}{*}{ Replications } & \multirow{2}{*}{ Control (-) } & \multicolumn{5}{|c|}{ Concentrations of extract } \\
\hline & & $10 \%$ & $12.5 \%$ & $16 \%$ & $25 \%$ & $50 \%$ \\
\hline 1 & 06.03 & 10.30 & 10.44 & 12.30 & 13.59 & 14.43 \\
\hline 2 & 07.15 & 09.40 & 11.28 & 12.02 & 12.25 & 15.20 \\
\hline 3 & 06.08 & 11.00 & 11.50 & 13.23 & 13.23 & 15.00 \\
\hline 4 & 08.47 & 09.27 & 10.23 & 11.15 & 13.44 & 15.38 \\
\hline 5 & 08.05 & 09.17 & 11.45 & 13.54 & 15.50 & 16.05 \\
\hline 6 & 05.56 & 08.06 & 10.58 & 11.11 & 13.47 & 13.53 \\
\hline 7 & 07.10 & 10.15 & 11.31 & 12.42 & 14.31 & 15.05 \\
\hline 8 & 06.21 & 09.54 & 11.29 & 12.00 & 14.10 & 14.25 \\
\hline Average blood clotting time (mins) & 07.23 & 10.01 & 11.01 & 12.22 & 14.03 & 15.26 \\
\hline
\end{tabular}

\section{DISCUSSION}

The anticoagulant activity test in this study was used by the Lee and White method with human blood samples. The length of time the blood clotting in the tube was indicated the anticoagulant activity of the Dayak 
onion onion bulb extract. The use of Dayak onion bulb (Eleutherine bulbosa) as an anticoagulant was based on the presence of eleutherinol content. Eleutherinol was a compound derived from naphthoquinone in Dayak onion bulb extract, which has the potential to reduce the rate of blood clotting ${ }^{(9)}$.

Based on Table 1, the negative control group was showed the formation of blood clots with an average time of 7 minutes 23 seconds which indicates standard clotting time. Meanwhile, the treatment group the extract in the concentration of $10 \%, 12.5 \%, 16 \%, 25 \%$ and $50 \%$ were known to have delayed blood coagulation. These results were indicated by a more extended blood clotting period compared to the control group. The mechanism of this action was the inhibition of prothrombin synthesis by this eleutherinol compound, which was worked antagonistically with vitamin $\mathrm{K}$. If the prothrombin level is low, blood clotting will be inhibited ${ }^{(12)}$.

Group of 50\% Dayak onion onion bulb extract had the effect of the longest coagulation time (Table 1). This result may because of the content of eleutherine that has a weak and transient effect og decreasing the prothrombin time in rats ${ }^{(18)}$. However, the biggest mean difference in blood clotting time (38\%) was in the addition of $10 \%$ extract compared to the control. While the difference between groups of concentrations were $10 \%-12.5 \%$, concentrations $12.5 \%$ - 16\%, concentrations $16 \%$ - 25\%, and concentrations of $25 \%-50 \%$ were $10 \%, 11 \%, 15 \%$, and $9 \%$, respectively. Normally, the increase in concentration should be provided with an increasing difference in time, but in this study, this did not happen. This phenomenon is presumably because the anticoagulant activity of Dayak bulbs in low concentration may have different mechanisms of inhibition.

The inhibition of blood coagulation activity was not optimum due to blood clotting formation in the treatment group, even though it had an increase in time compared to the control group. Some authors were stated different normal blood clotting time range; 3-18 minutes ${ }^{(13)}$ and 4-8 minutes. Furthermore, to obtain coagulation activity for 4-6 hours, it was necessary to observe blood clots for 120 minutes ${ }^{(14)}$. Another cause of blood clotting may because of the insufficient volume of extract added to the blood $(10 \mu \mathrm{l})$, thus affecting its inhibitory ability. The addition of anticoagulant (Dayak onion onion bulb extract) with a ratio of blood volume was 1: 100, due to utilization of commercial anticoagulants, namely ethylenediaminetetraacetic acid (EDTA) ${ }^{(15)}$. The optimal anticoagulant volume can be determined through the titration method ${ }^{(16)}$. Although the Dayak onion bulb extract has blood clotting inhibitory activity, it is not sufficient to stop the blood clotting process as well as commercial anticoagulants.

\section{CONCLUSION}

Dayak onion bulb extract (Eleutherine bulbosa) at concentrations of 10, 12.5, 16, 25, and 50\% had anticoagulation activity against human blood. The blood clotting time was increased, as the concentration increased, especially at a concentration of $12.5 \%$, which can inhibit the blood coagulation rate by $52 \%$.

\section{REFERENCES}

1. Setiabudi R. Farmakologi dan Terapi. Jakarta: Departemen Farmakologi dan Terapeutik, FKUI; 2009.

2. Dewoto HR. Farmakologi dan Terapi: Antikoagulan, Antitrombotik, Trombolitik dan Hemostatik. Jakarta: Departemen Farmakologi dan Terapeutik FKUI; 2009.

3. Gross PL, Weitz JL. New Antithrombotic Drugs. 2009.

4. Tangkery RAB, Paransa DS, Rumengan A. Uji Aktivitas Antikoagulan Ekstrak Mangrove Aegiceras corniculatum. 2013;1:7-14.

5. Schnauck W, Mayer K, Haake M. Senyawa Obat. Yogyakarta: Gadjah Mada University Press; 1990.

6. Chanarin I. Laboratory Haematology An Account of Laboratory Techiques. London: Churchill Livingstone; 1991.

7. Rahmawati, Fawwas M, Razak R, Islmiati U. Potensi Antikoagulan Sari Bawang Putih (Allium sativum) Menggunakan Metode Lee-White dan Apusan Darah. 2018;14(1):42-48

8. Haerani A, Chaerunisa AY, Subarnas A. Antioxidant Activities of Muntingia calabura, Syzygium cumini, Ocimum basilicum, and Eleutherine bulbosa using DPPH Method. 2019;1(2).

9. Bahtiar A, Annisa R. Effects of Dayak Onion Bulbs (Eleutherine bulbosa (Mill.) Urb) on Bone Development of the Hipoestrogen Model Rat. 2018;10(2):299-303.

10. Han AR. Identification of A New Naphtalene and Its Derivates from Bulb of Eleutherine americana with Inhibitory Activity on Lipopolysaccharide-Induced Nitric Oxide Production. Chemical Pharmacy Bulletin. 2008;56.

11. Rimainar A, Sigit JI, Adnyana IK. Uji Efek Antiagregasi Platelet Ekstrak Air dan Etanol Umbi Eleutherine palmofolia (L.) Merr. terhadap Mencit Jantan Galur Swiss Webster. 2012.

12. Chen D, Hu M, et al. New Naphthalene Derivatives from the Bulbs of Eleutherine americana with Their Protective Effect on the Injury of HUVECs. 2018;1-9.

13. Bithell T. The Diagnostic Approach To The Bleeding Discordes. Pennsylvania: Wintrobe's Clinical Hematology; 1993.

14. Mutschler E. Dinamika Obat. In Buku Ajar Farmakologi dan Toksikologi. Bandung: ITB; 1991.

15. Wirawan R, Silman E. Pemeriksaan Laboratorium Hematologi Sederhana. Jakarta: Balai Penerbit FKUI; 2000.

16. Weliyani, Nugroho RA, Syafrizal. Uji Aktivitas Antikoagulan Ekstrak Propolis Trigona laeviceps Terhadap Darah Mencit (Mus musculus L.). 2015:1-10.

17. Gandasoebrata. Penuntun Labooratorium Klinis. Jakarta: Dian Rakyat; 2013.

18. Bianchi C, Ceriotti G. Chemical and Pharmacological Investigations of Constituents of Eleutherine bulbosa (Miller) Urb. (Iridaceae). Journal of Pharmaceutical Sciences. 1975;64(8):1305-1308. 